\title{
Getting It Wrong From the Beginning: Our Progressivist Inheritance from Herbert Spencer, John Dewey, and Jean Piaget
}

\author{
By: Kieran Egan
}

\author{
Reviewed by Mary Caroline Rowan
}

\begin{abstract}
Mary Caroline Rowan is a Vanier scholar and $\mathrm{PhD}$ student in the faculty of education at the University of New Brunswick. She completed her masters degree at the School of Child and Youth Care, University of Victoria, in November 2011, defending her thesis Exploring the Possibilities of Learning Stories as a Meaningful Approach to Early Childhood Education in Nunavik.
\end{abstract}

In Getting It Wrong From the Beginning: Our Progressivist Inheritance from Herbert Spencer, John Dewey, and Jean Piaget, Egan (2002) examines the theoretical backbone of our current educational theories and, in the process, exposes troubled foundations. In this concise and immensely readable volume (204 pages), Egan fastidiously links Herbert Spencer's 19th-century educational principles with two of the most influential contributors to ongoing educational practice, John Dewey and Jean Piaget. In the process, he problematizes the limitations of a so-called natural, linear, staged progression of children's growth as defined by developmental psychology, which he reveals is rooted in Spencer's adherence to long-discounted Lamarckian theories of evolution. As a teacher of early childhood educators and administrators and as a student of early childhood education, I find Egan's book to provide many useful insights.

Egan calls the current state of schooling a catastrophe, lamenting impoverished anemic curriculum and "unforgivable ignorance" $(p$. 148). He is concerned that the perpetuation of child-centred, science-based, progressivist thought disables efforts "to make schooling more effective" (p. 8). He shows how 19th-century theory infuses what many teachers view to be the tenets of early childhood education, including the ideas that children learn through hands on, self-directed play and discovery, that knowledge builds on prior learning, and that learning should be pleasant and supported by the knowing teacher who acts as a facilitator (p. 42). Egan, unsatisfied with a lack of history, grammar, memory work, and rigour in contemporary education, draws on the work of Vygotsky and Wertsch to explain the sociocultural nature of learning. He argues for the value of directing research investments and studies to understand the processes involved in acquiring cultural cognitive tools, thereby opening educators to the possibilities of imaginative engagements and effective learning.
Egan finds two main faults with progressivist thought: first, that planned learning is essentially different from incidental/ absorptive/experiential learning; second, that Spencer's approach is based on the premise that by coming to know the child through scientific study, teaching and learning can be improved. Egan cites Howard Gardner $(1983,1993)$ to help make the case for the diversity of human learning. Gardner (cited in Egan, 2002) writes: "Empirical evidence shows that the mindhuman or pre-human -is distinguished by the fact that it does not ... harbor all-purpose rules or operations" (p. 58). Egan fortifies this line of reasoning by referencing Hirst (1974), who argues that it is not possible to track the workings of the mind. He writes: "If there are regularities to be seen, they are produced by the regularities of having socialized children and having taught them certain forms of knowledge at regular times" (Hirst, cited in Egan, 2002, p. 82). This claim challenges a fundamental progressivist notion of the knowable child.

Within his text, Egan develops carefully crafted challenges to Spencer's principles for intellectual education, which include the following:

- Mind develops from homogeneous to heterogeneous: simple to complex.

- Mind develops from chaos to clarity: indefinite to definite.

- Lessons should start with the concrete and move to the abstract.

- The progress of the developing mind follows principles of recapitulation theory.

- Instruction proceeds from practical to complex.

- The curriculum is child centred-the child is the investigator and the teacher the facilitator.

- Learning should be pleasant. 
According to Egan, Spencer "followed the mid-nineteenth-century conviction that the human race went through-recapitulatedall of the stages of development of our species, from a simplecelled creature, through gilled fishlike ancestors, and so on, to the present" (p. 27). Egan writes about Spencer's casual and brutal racism and explains that Spencer's theories were used to view other races as inferior. He argues that Spencer's flawed theories "profoundly shape current practice" (p. 34) and provides examples of influential educational thinkers who subscribed to the same racist thinking. These include G. Stanley Hall, father of the developmental checklist, and John Dewey, both of whom took up recapitulationist discourses. Dewey wrote that there "is a sort of natural recurrence of the child mind to the typical activities of primitive people" (Gould, 1977, cited in Egan, 2002, p. 27). Egan also includes James Sully, the British leader of the child study movement, in this list. He reports Sully (1895) as saying, "As we all know, the lowest races of mankind stand in close proximity to the animal world. The same is true for infants of the civilized races" (cited in Egan, 2002, p. 91).

Recapitulation theory is used to construct ideas of racialization and perpetuate racist practices. I find this deeply concerning, and I am disturbed by Egan's connecting of Spencer's racist foundations with educational influencers including Spencer, Hall, Dewey, and Sully. I am led to conclude that much of current educational thinking is grounded in structures founded on racist perspectives and that these structures perpetuate practices of racialization in contemporary educational practice. How, I ask, can we as practitioners of early childhood education become aware of, identify, and disrupt these dividing forces that are so insidious and invisible?
In addition to raising awareness of the problems connected with Spencer's influence, Egan makes several important contributions. By carefully deconstructing issues with the principles upon which developmental psychology is founded, Egan provides substantive content to explain problems linked with developmental psychology, including its blindness to cultural influences, adherence to linear processes, and the flawed idea that a child's mind is primitive and can be known through scientific research. Egan also raises awareness of compromised academic content when learning is directed to purposes of socialization. He does not, however, simply criticize Spencer's theories and Piaget's stages and operations. He sets out to point to solutions. He suggests that "what we know forms a resource for our imaginations" (p. 137) and that imaginative engagement leads to "genuine educational experience" (p. 176).

Egan proposes that richer educational experiences can be cultivated by doing the following: focusing educational research to intentionally gain insights into the cultural-cognitive tools that shape learning; working with an overarching theory of education; creating opportunities for children to acquire a wide base of intellectual resources; and eliminating the barriers to learning imposed by notions of ages and stages. These are ideas which, I find, present abundant possibilities for early childhood settings.

\section{Reference}

Egan, K. (2002). Getting it wrong from the beginning: Our progressivist inheritance from Herbert Spencer, John Dewey, and Jean Piaget. New Haven, CT: Yale University Press.

\section{Friends of Children Award Guidelines}

The CAYC "Friends of Children Award" was established to give CAYC a way of recognizing outstanding contributions, by individuals or groups to the well-being of young children. If you wish to nominate an individual or group for this award, please use the criteria and procedure below.

\section{CRITERIA}

The Friends of Children Award may be presented to an individual or group, regardless of age, who:

- Has a history of commitment to the CAYC mission statement and/ or aims.

- Has shown an outstanding scholarly, advocacy, innovative or practical contribution to the well-being of young children.

- May or may not be of Canadian citizenship.

- May or may not hold CAYC membership although it is encouraged.

\section{PROCEDURE}

- A nomination must be made by a member of the Board of Directors and be seconded by a member of the Board of Directors. Board members can, however, receive recommendations for nominations from individual CAYC members or from other organizations. - Nominations will be brought forward at a Board of Directors or National Executive meeting by the board or executive member assigned responsibility for the award. This board or executive member will present and speak to the nomination.

- The nomination will be voted upon and passed by the Board of Directors with a consensus decision.

- The award will be presented promptly and in person when possible.

- Publicity of the award and the recipient(s) will appear in the journal, Canadian Children, and other publications where possible.

- The number of awards per year will vary. 